\title{
A method to quantify changes in supply of metabolizable methionine to dairy cows using concentrations of selenium in milk
}

\author{
W. P. Weiss ${ }^{1}$ and N. R. St-Pierre \\ Department of Animal Sciences, The Ohio State University, Wooster 44691
}

\section{ABSTRACT}

A method that accurately quantifies changes in the supply of metabolizable Met following a dietary change will allow accurate economic comparisons of various Met sources. This paper describes a novel method of estimating the relative supply of metabolizable Met based on changes in the concentration of Se in milk. Selenized yeast (Se-yeast) contains selenomethionine (Se-met) and because Se-met and Met are indistinguishable by cells, Se-met can be used as a tracer of Met. We hypothesized that if the size of the Met pool was increased but intake of Se-met was constant, the concentration of Se in milk relative to milk Met would decrease. To test this hypothesis, 6 Holstein cows were fed a diet that contained $0.3 \mathrm{mg}$ of Se from Se-yeast/ $\mathrm{kg}$ of diet DM and then in a 2-period crossover experiment, were abomasally infused with water (control) or an aqueous solution that provided $9 \mathrm{~g}$ of Met/d. Milk was sampled during the infusion and the specific activity (SA) of milk (Se concentration divided by Met concentration) was calculated for each treatment. The SA in milk from Met-infused cows was divided by SA in milk from control cows to calculate the change in supply of metabolizable Met. As hypothesized, infusing Met reduced the SA of milk (84.7 vs. $72.5 \mu \mathrm{g}$ of Se/mg of Met). The calculated flow of metabolizable Met was $17 \%$ greater when cows were infused with $9 \mathrm{~g}$ of Met/d compared with cows infused with water (essentially the same difference was measured using SA calculated with $\mathrm{N}$ concentrations of milk). Assuming the infused Met was $100 \%$ absorbed, the flow of metabolizable Met for control cows was $9 / 0.17=53 \mathrm{~g}$ of Met/d, which agreed well with literature data and estimates derived from common nutritional models.

Key words: methionine, milk protein, tracer, selenium

Received November 10, 2008.

Accepted February 10, 2009.

${ }^{1}$ Corresponding author: weiss.6@osu.edu

\section{INTRODUCTION}

Methionine is often the limiting amino acid for protein synthesis by lactating dairy cows and increasing its supply can increase the concentration and yield of milk protein (NRC, 2001). Increasing the supply of metabolizable Met (i.e., Met that is absorbed from the intestines and is available to cells to be oxidized or used to synthesize protein) to a dairy cow usually requires the use of expensive feedstuffs or supplements such as fish meal, corn gluten meal, and rumen-protected Met. The ability to quantify the effect of a dietary modification on Met supply makes accurate economic comparisons of feedstuffs and supplements possible.

Various methods have been developed to estimate or measure effects of diet modification on Met flow. The supply of metabolizable Met can be measured using cows with duodenal and ileal cannulas (Berthiaume et al., 2001), but the need for surgically modified animals and relatively high experimental error limits the value of this method. Nutrition models such as NRC (2001) and the CPM model (CPM Dairy nutrition model; version 3.0; Cornell University, Ithaca, NY; University of Pennsylvania, Kennett Square, PA; and William H. Miner Agricultural Research Institute, Chazy, NY) can be used to estimate the supply of metabolizable Met, but the errors associated with the estimates can be substantial (Pacheco et al., 2006). Changes in the concentration of Met in plasma and in arterial-venous differences have been used to monitor changes in the supply of metabolizable Met (Casper and Schingoethe, 1988; Sudekum et al., 2004). These methods allow qualitative, not quantitative, ranking of the ability of diets to supply metabolizable Met, and concentrations and arterial-venous differences in plasma Met do not always change when the supply of metabolizable Met changes (Casper and Schingoethe, 1988). Changes in metabolizable Met supply also can be qualitatively evaluated by measuring yields and concentrations of milk protein (Rulquin et al., 2006); however, increasing the amount of Met absorbed by the small intestine does not always increase milk protein because other factors may be first limiting (Berthiaume et al., 2001). 
Table 1. Ingredient and nutrient composition of the diet

\begin{tabular}{|c|c|}
\hline Ingredient & $\%$ of DM \\
\hline Corn silage ${ }^{1}$ & 40.0 \\
\hline Alfalfa silage $^{1}$ & 20.2 \\
\hline Corn grain, ground & 19.40 \\
\hline Soybean meal, $44 \%$ CP & 13.56 \\
\hline Soyhulls & 5.00 \\
\hline Animal vegetable fat & 0.40 \\
\hline Limestone & 0.74 \\
\hline Trace mineral salt (no Se) & 0.50 \\
\hline Dicalcium phosphate & 0.18 \\
\hline Se-yeast ${ }^{2}$ & 0.049 \\
\hline Trace mineral/vitamin $\operatorname{mix}^{3}$ & 0.093 \\
\hline \multicolumn{2}{|l|}{ Nutrient composition } \\
\hline $\mathrm{CP}$ & 14.7 \\
\hline NDF & 35.8 \\
\hline Total Se, ${ }^{4} \mathrm{mg} / \mathrm{kg}$ & 0.40 \\
\hline
\end{tabular}

${ }^{1}$ Corn silage contained $7.5 \% \mathrm{CP}$ and $44.0 \% \mathrm{NDF}$; alfalfa silage contained $17.2 \% \mathrm{CP}$ and $44.4 \% \mathrm{NDF}$ (DM basis).

${ }^{2}$ Selenosource AF 600 (Diamond V Mills Inc., Cedar Rapids, IA). Product contained $600 \mathrm{mg}$ of $\mathrm{Se} / \mathrm{kg}$.

${ }^{3}$ Premix contained 4,000,000 IU of vitamin A, 1,100,000 IU of vitamin $\mathrm{D}, 21,000 \mathrm{IU}$ of vitamin $\mathrm{E}, 3,200 \mathrm{mg}$ of $\mathrm{Cu}$ (from copper sulfate), and 4,650 $\mathrm{mg}$ of $\mathrm{Zn}$ (from zinc sulfate) per kilogram.

${ }^{4}$ Includes Se provided from the Se-yeast and Se in feedstuffs.

The objective of this experiment was to evaluate a novel method of quantifying changes in the entry rate of Met into its metabolically available pool based on changes in the concentration of Se in milk. When cows are fed Se-yeast, a substantial amount of the Se in the milk is in the form of selenomethionine (Muniz-Naveiro et al., 2007). We hypothesized that dietary Se-yeast can be used to label the Met pool with selenomethionine (Se-met), and that the concentration of Se (a proxy for Se-met) in milk protein changes in response to changes in the entry rate of Met.

\section{MATERIALS AND METHODS}

All procedures involving animals were approved by the Agricultural Animal Care and Use Committee of The Ohio State University.

\section{Cows and Treatments}

Prior to the start of the experiment, cows were housed in free stalls and fed a common diet that contained approximately $0.3 \mathrm{mg}$ of supplemental Se from sodium selenate/kg of DM (the diet without supplemental Se contained approximately $0.1 \mathrm{mg}$ of $\mathrm{Se} / \mathrm{kg}$ of DM). Cows consumed only that source of supplemental Se for at least 6 mo before this experiment. Milk samples (a.m. and p.m.) were taken from cows for 2 consecutive days immediately before the experiment started when cows were consuming inorganic Se. Six rumen-cannulated pregnant Holstein cows that averaged $150 \mathrm{~d}$ of gesta- tion $(\mathrm{SD}=43)$ and 253 DIM $(\mathrm{SD}=36)$ were moved into individual tie stalls and fed a common diet (Table 1) that contained Se-yeast (Selenosource AF 600 kindly donated by Diamond V Mills, Cedar Rapids, IA) and provided $0.3 \mathrm{mg}$ of $\mathrm{Se} / \mathrm{kg}$ of diet DM (no other source of supplemental Se was fed). Cows were milked twice daily and fed a TMR once daily (approximately 5\% orts). After $15 \mathrm{~d}$, samples from 4 consecutive milkings were taken and abomasal infusions started but diets were held constant.

An abomasal infusion apparatus was assembled and placed in the abomasum of each cow as described by Gressley et al. (2006). Briefly, an infusion line (Tygon tubing, i.d. $4.8 \mathrm{~mm}$; Cole-Parmer Instrument Co., Vernon Hills, IL) was passed through the ruminal cannula and anchored into the abomasum with a rubber flange. Placement of the infusion line in the abomasum was checked twice a day. During a 4 -d infusion period, 3 cows were infused with tap water at an average rate of $375 \mathrm{~mL} / \mathrm{h}$, and 3 cows were infused with $375 \mathrm{~mL} / \mathrm{h}$ of an aqueous solution of $1 \mathrm{~g} / \mathrm{L}$ of DL-Met (Acros Organics, Geel, Belgium; $9.0 \mathrm{~g}$ of Met/d) using peristaltic pumps. After the afternoon milking on the fourth day of the infusion, lines were removed. Milk was sampled from the last 4 milkings during the infusion period (approximately $48,60,72$, and $84 \mathrm{~h}$ after the start of the infusion). After the infusion period, cows were fed the same diet for another $11 \mathrm{~d}$ and milk was sampled from 4 consecutive milkings and another infusion period started. The infusion and sampling protocol was then repeated except that the infusion treatments given to cows were switched.

\section{Sample Analyses}

Samples of corn silage, alfalfa silage, and concentrate were collected daily during each infusion period and composited. Samples were dried in a forced-air oven for $24 \mathrm{~h}$ at $55^{\circ} \mathrm{C}$, ground to pass through a $1-\mathrm{mm}$ screen of a Wiley mill (Arthur H. Thomas, Philadelphia, PA), and analyzed for $\mathrm{DM}\left(100^{\circ} \mathrm{C}\right.$ oven for $\left.8 \mathrm{~h}\right)$, NDF using sodium sulfite and $\alpha$-amylase (Ankom200 Fiber Analyzer; Ankom Technology, Fairport, NY), Kjeldahl N (AOAC, 2000), and Se (described below). Milk samples (a.m. and p.m.) were composited by day and analyzed for Kjeldahl N (AOAC, 2000) and Se. Selenium in feed and milk was assayed using a fluorometric method (Koh and Benson, 1983) after digesting in a 4:1 (vol/ vol) mixture of concentrated nitric acid and $11.6 \mathrm{M}$ perchloric acid. Appropriate standards and a National Institute of Standards and Technology reference material (milk powder, NIST \#1549, Gaithersburg, MD) were analyzed with each run. The concentration of Met was measured in milk samples taken during the 


\section{Small Intestine}

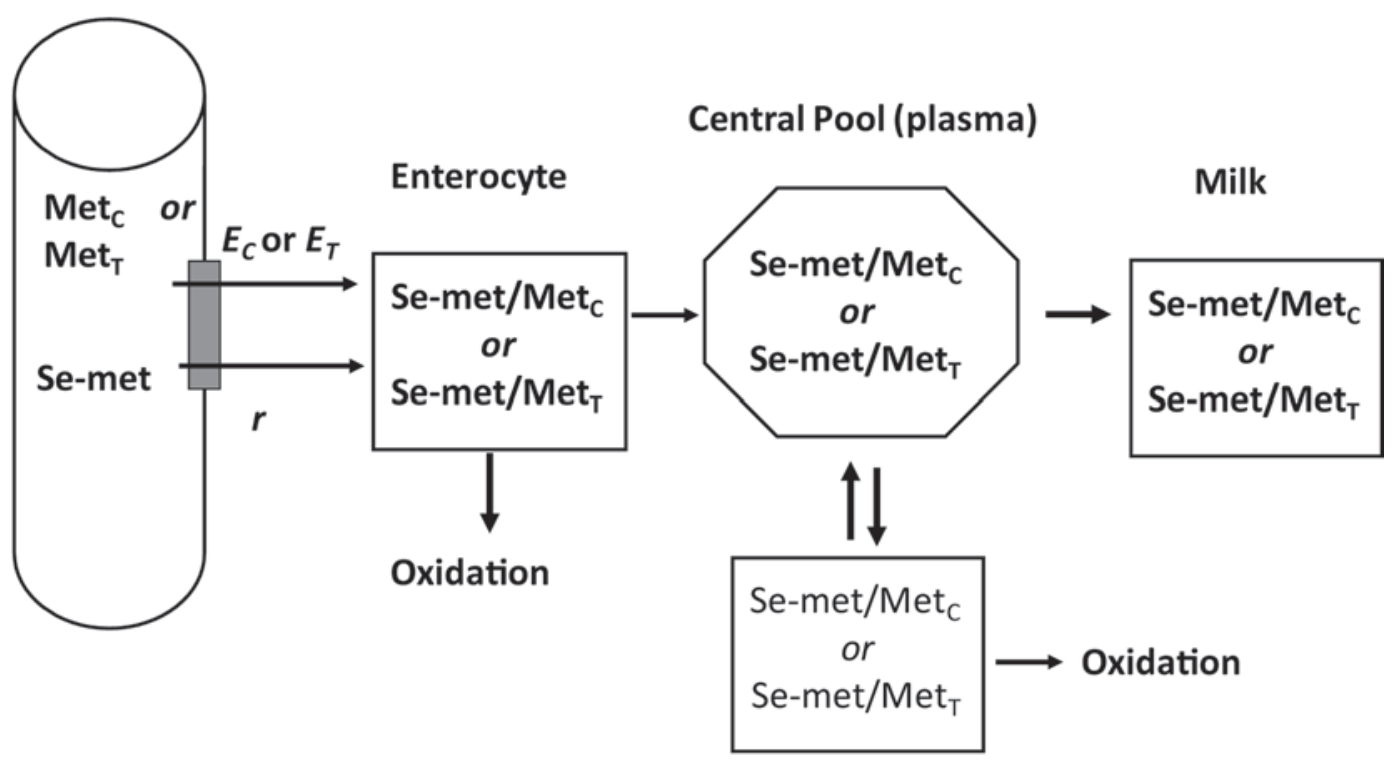

\section{Other Tissues}

Figure 1. Simplified kinetic model of metabolism of methionine and use of selenomethionine (Se-met) as a tracer. Met ${ }_{\mathrm{C}}$ and Met $_{\mathrm{T}}$ represent the concentrations of Met in various pools within cows fed a control $(\mathrm{C})$ or treatment $(\mathrm{T})$ diet. Daily entry rate (g/d) of Met into enterocytes is designated by $\mathrm{E}_{\mathrm{C}}$ or $\mathrm{E}_{\mathrm{T}}$ and will vary with treatment. Daily entry rate of Se-met $(\mathrm{mg} / \mathrm{d})$ is designated by $\mathrm{r}$, is a function of Se-yeast consumption, and will not vary with treatment. When steady state is obtained, specific activity (e.g., Se-met/Met) will be equal within all tissues and in the Met that is oxidized. Sampling milk and measuring its SA will directly correlate with the SA of the Met absorbed from the intestine.

infusion period. Milk samples were lyophilized to approximately $90 \% \mathrm{DM}$ and then assayed for total Met by the University of Missouri Agricultural Experiment Station Chemical Laboratories, Columbia per AOAC (2006; $982.30 \mathrm{E}(\mathrm{a}))$ methods.

\section{Calculations}

The premise of this kinetic model is that feeding Seyeast is equivalent to a constant infusion of labeled Met (i.e., Se-met) into the Met pool. A simplified model of Met absorption and metabolism is shown in Figure 1. No evidence exists suggesting that intestinal absorption of Se-met and Met occur via different mechanisms or that cells preferentially utilize (via oxidation or protein synthesis) or transport one form of Met over the other. Therefore, Se-met will follow the same pathways as Met, but the daily entry rate from the intestine for Se-met (designated by $\mathrm{r}$ in Figure 1) and Met (designated by $\mathrm{E}_{\mathrm{C}}$ or $\mathrm{E}_{\mathrm{T}}$ in Figure 1) will differ. Entry rate of Se-met is a function of the amount of Se-met (i.e., Se-yeast) consumed, whereas entry rate of Met is a function of rumen microbial protein synthesis and the amount of Met provided by digestible RUP.

If Se-met is fed for a long enough period, all labile pools of Met will be labeled uniformly with Se-met. After Met pools are in steady state with respect to
Se-met and with continued feeding of Se-yeast, all entry of Met into the central Met pool (i.e., plasma) will be directly proportional to entry of Se-met into that pool (Figure 1). The Se-met specific activity (SA) in milk (concentration of Se-met divided by concentration of Met) will be directly proportional to the SA of absorbed Se-met (i.e., r/E in Figure 1). Therefore, if a diet modification is made that increases the amount of Met that is absorbed from the intestine ( $\mathrm{E}$ in Figure 1), the SA of Se-met in Met pools (including milk) will decrease (i.e., the Se-met will be diluted) proportionally to the increase in the supply of metabolizable Met coming from the intestines.

The entry (E) of Met can be calculated as (Shipley and Clark, 1972):

$$
\mathrm{E}=\mathrm{r} / \mathrm{SA}
$$

where $\mathrm{r}=$ rate of entry of Se-met (mg of Se-met/d) and $\mathrm{SA}=$ specific activity of a pool $(\mathrm{mg}$ of Se-met $/ \mathrm{g}$ of Met).

The actual entry of Se-met (r) when Se-yeast is fed will not be known, which precludes calculation of the actual entry rate of Met; however, our method is designed to calculate relative entry of Met following a diet modification such as changing source of supplemental dietary protein. For calculation of the relative entry of 
Met, knowing the actual entry of Se-met is not necessary. Cows must be fed at least 2 different diets, for example, control and treatment, and both diets must contain the same concentration of Se-yeast so that $r$ (Figure 1) is the same for both treatments. The entry rates of Met when cows are fed the control diet $\left(\mathrm{E}_{\mathrm{C}}\right)$ or the treatment $\operatorname{diet}\left(\mathrm{E}_{\mathrm{T}}\right)$ are, respectively:

$$
\begin{aligned}
& \mathrm{E}_{\mathrm{C}}=\mathrm{r} / \mathrm{SA}_{\mathrm{C}} \\
& \mathrm{E}_{\mathrm{T}}=\mathrm{r} / \mathrm{SA}_{\mathrm{T}}
\end{aligned}
$$

where $\mathrm{r}=$ entry rate of Se-met and $\mathrm{SA}_{\mathrm{C}}$ and $\mathrm{SA}_{\mathrm{T}}=\mathrm{SA}$ (Se-met/Met) in milk from cows fed the control diet or treatment diet, respectively.

Equations [2] and [3] can be combined and rearranged to:

$$
\mathrm{E}_{\mathrm{T}}=\mathrm{E}_{\mathrm{C}} \times\left(\mathrm{SA}_{\mathrm{C}} / \mathrm{SA}_{\mathrm{T}}\right) .
$$

The ratio of SA is calculated from experimental data and equals the proportional change in Met entry rate for the treatment relative to the control. The actual entry rate is not known but if an estimate of entry rate of Met can be obtained for the control diet (e.g., via a nutritional model), then an entry rate for the experimental diet can be estimated by multiplying it by the ratio of SA for control and treatment cows.

In the above calculations, SA is defined as the concentration of Se-met divided by the concentration of Met. Both Met and Se-met can be assayed in biological samples; however, the analyses, especially for Se-met, are difficult and require expensive and specialized equipment. For this method, we used concentration of milk Se as a proxy for Se-met concentration, and also evaluated whether milk $\mathrm{N}$ could serve as a proxy for milk Met. Assuming Se and Se-met were interchangeable results in the final equations:

$$
\begin{gathered}
\mathrm{E}_{\mathrm{T}}=\mathrm{E}_{\mathrm{C}} \times\left\{\left(\mathrm{Se}_{\mathrm{C}} / \mathrm{Met}_{\mathrm{C}}\right) /\left(\mathrm{Se}_{\mathrm{T}} / \mathrm{Met}_{\mathrm{T}}\right)\right\} \text { or } \\
\mathrm{E}_{\mathrm{T}}=\mathrm{E}_{\mathrm{C}} \times\left\{\left(\mathrm{Se}_{\mathrm{C}} / \mathrm{N}_{\mathrm{C}}\right) /\left(\mathrm{Se}_{\mathrm{T}} / \mathrm{N}_{\mathrm{T}}\right)\right\}
\end{gathered}
$$

where $\mathrm{E}_{\mathrm{C}}$ and $\mathrm{E}_{\mathrm{T}}=$ entry rates of Met when cows are fed control or treatment diets, and milk concentrations of Se $(\mathrm{mg} / \mathrm{kg})$, Met $(\mathrm{g} / \mathrm{kg})$, and $\mathrm{N}(\mathrm{g} / \mathrm{kg})$ from cows fed control or treatment diets are designated as $\mathrm{Se}_{\mathrm{C}}$ and $\mathrm{Se}_{\mathrm{T}}, \mathrm{Met}_{\mathrm{C}}$ and $\mathrm{Met}_{\mathrm{T}}$, and $\mathrm{N}_{\mathrm{C}}$ and $\mathrm{N}_{\mathrm{T}}$, respectively.

\section{Statistics}

Milk Se data from each pair of consecutive days was composited (within cow) yielding a sample when selenate was fed, a sample before the start of each infusion period, a sample about $3 \mathrm{~d}$ after the first infusion period, and samples during each infusion period. Milk samples taken during the infusion provided the data central to the experiment and were analyzed statistically. Data from other milk samples were used to provide evidence that Se-yeast increased milk Se, cows had reached steady state with respect to milk Se, and that the washout period between infusions was adequate. Data collected during the infusion period were analyzed using PROC MIXED (SAS Institute, 2004). The model included treatment sequence (1 df, fixed), cows nested within sequence (4 df, random), period (1 df, random), treatment ( $1 \mathrm{df}$, fixed), and error $(4 \mathrm{df})$.

\section{RESULTS AND DISCUSSION}

The concentration of Se in milk when cows were fed inorganic Se was $0.020 \mathrm{mg} / \mathrm{L}$ (Figure 2), which is similar to previous data (Weiss and Hogan, 2005; Juniper et al., 2006; Heard et al., 2007). The average concentration of Se during the Se-yeast feeding period (excluding the infusion period) was $0.048 \mathrm{mg} / \mathrm{L}$, or 2.45 times greater than when inorganic Se was fed. A review of 10 experiments reported a median increase in milk Se of 1.9 when Se-yeast replaced inorganic Se with a range of 1.1 to 2.7 (Weiss, 2005). The concentration of Se in milk increases rapidly when inorganic Se is replaced with Se-yeast and appears to reach steady state within $7 \mathrm{~d}$ (Heard et al., 2007). The concentration of Se in milk in our study when Se-yeast was fed was stable (excluding the infusion period) throughout the experiment (Figure 2).

During the infusion, DMI and yields of milk and milk $\mathrm{N}$ were not different between treatments, but infusion of Met increased $(P<0.05)$ the concentration of $\mathrm{N}$ in milk (Table 2). Post-ruminal infusion of Met often increases the concentration of milk protein but not necessarily the yield of milk protein (Guinard and Rulquin, 1995; Pisulewski et al., 1996). The increase in the concentration of milk $\mathrm{N}$ when Met was infused provides evidence that the infusion had a biological response, but it is not possible to quantify the amount of Met absorbed from the change in milk protein concentration.

\section{Calculated Entry Rate of Methionine}

The concentration of Se in milk from cows infused with Met was about $10 \%$ lower $(P<0.11)$ than that from cows infused with water (Table 2). Based on our hypothesis, infusing Met would dilute the Se within the milk protein pool (i.e., pool with Met) which would decrease the SA ( $\mu \mathrm{g}$ of Se/g of Met); the concentration of Se in milk may or may not change. The concentra- 
Table 2. Effect of an abomasal infusion of DL-methionine on DMI, milk production, milk N, and milk Se ${ }^{1}$

\begin{tabular}{lcccc}
\hline Item & Control & Methionine & $\mathrm{SE}$ & $P$-value \\
\hline $\mathrm{DMI}, \mathrm{kg} / \mathrm{d}$ & 21.5 & 21.2 & 1.48 & $<0.5$ \\
Milk, kg/d & 27.5 & 27.1 & 2.32 & $<0.5$ \\
Milk N, g/kg & 4.74 & 5.01 & 0.10 & $<0.05$ \\
Milk N, g/d & 131 & 135 & 8.8 & $<0.35$ \\
Milk Met, g/kg of milk & 0.79 & 0.82 & 0.023 & $<0.27$ \\
Milk Met, g/kg of milk CP & 25.2 & 24.9 & 0.31 & $<0.5$ \\
Milk Se, mg/kg & 0.067 & 0.060 & 0.005 & $<0.11$ \\
Milk Se/milk Met, $\mu \mathrm{g} / \mathrm{g}$ & 84.7 & 72.5 & 5.3 & $<0.02$ \\
Milk Se/milk N, $\mu \mathrm{g} / \mathrm{g}$ & 14.1 & 11.8 & 0.90 & $<0.02$ \\
\hline
\end{tabular}

${ }^{1}$ Cows were infused with $9 \mathrm{~L} / \mathrm{d}$ of water or a methionine solution $(1 \mathrm{~g}$ of Met/L of water) for $4 \mathrm{~d}$.

tion of Se per unit of milk Met ( $\mu \mathrm{g}$ of Se/g of Met) was $14.4 \%$ lower $(P<0.02)$ and per unit of milk $\mathrm{N}(\mu \mathrm{g}$ of $\mathrm{Se} / \mathrm{g}$ of milk $\mathrm{N})$ it was $16.3 \%$ lower $(P<0.02)$ when Met was infused (Table 2) which is consistent with our hypothesis and supports the concept of our method. The relative entry rate of Met for infused cows using SA based on milk Met is (Equation [5a])

$$
\mathrm{E}_{\mathrm{T}}=\mathrm{E}_{\mathrm{C}}(84.7 / 72.5)=1.17 \times \mathrm{E}_{\mathrm{C}} .
$$

Using Equation [5b] (i.e., expressing SA on a milk N basis) yielded $\mathrm{E}_{\mathrm{T}}=1.19 \times \mathrm{E}_{\mathrm{C}}$. The similar results when either milk Met or milk $\mathrm{N}$ was used means that measuring milk $\mathrm{N}$ rather than milk Met is adequate. This was expected because the proportion of milk protein that is Met is essentially constant (Featherston et al., 1964). For simplicity, only the value calculated using milk N will be discussed further.

Because the actual increase in the quantity of absorbed Met when Met was infused is known (i.e., $9 \mathrm{~g} / \mathrm{d}$ assuming that it was $100 \%$ absorbed), the daily entry rate $(\mathrm{g} / \mathrm{d})$ of Met for infused cows can also be written

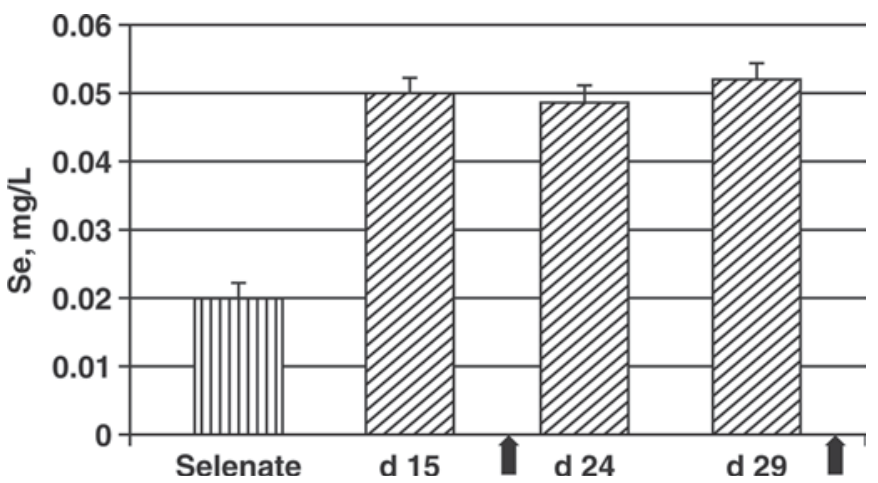

Figure 2. Concentrations of Se in milk during the experiment. Selenate bar represents samples taken when supplemental Se $(0.3$ $\mathrm{mg} / \mathrm{kg}$ ) was provided by sodium selenate (i.e., d 0). Starting on d 1, Se-yeast replaced selenate as the source of supplemental Se. Arrows designate periods when abomasal infusions of methionine or water occurred (d 17 through d 20 and d 30 through d33). The error bars are the SE. as $\mathrm{E}_{\mathrm{T}}=\mathrm{E}_{\mathrm{C}}+9$. Combining this equation with the one above $\left(\mathrm{E}_{\mathrm{T}}=1.19 \times \mathrm{E}_{\mathrm{C}}\right)$ and rearranging yields:

$$
\begin{gathered}
1.19 \times \mathrm{E}_{\mathrm{C}}=\mathrm{E}_{\mathrm{C}}+9, \\
\mathrm{E}_{\mathrm{C}}=9 / 0.19=47.4 \mathrm{~g} / \mathrm{d} \text { (daily entry rate of Met } \\
\text { by control cows), and } \\
\mathrm{E}_{\mathrm{T}}=\mathrm{E}_{\mathrm{C}}+9=56.4 \mathrm{~g} / \mathrm{d} \text { (daily entry rate of Met } \\
\text { when cows were infused with Met). }
\end{gathered}
$$

Cows in this experiment averaged 253 DIM and it is unlikely that mobilization of body protein caused a net increase in the entry rate of Met. Therefore, the total entry rate for these cows is actually an estimate of daily absorption of Met from the small intestine. Those values ( 47.4 and $56.4 \mathrm{~g} / \mathrm{d}$ ) are a net value and include any Met that is oxidized by splanchnic tissue. In sheep, approximately $10 \%$ of the Met absorbed was oxidized before reaching the general circulation (Lobley et al., 2003). If $10 \%$ oxidation is assumed, the amount of Met that reached the general circulation (i.e., net portal absorption) and was available for synthesis of milk protein for control cows was $47.4 \times 0.9=42.6$ $\mathrm{g} / \mathrm{d}$. That value compares well with the average net portal absorption of Met $(41 \mathrm{~g} / \mathrm{d})$ by lactating cows (Pacheco et al., 2006).

To provide additional evaluation of our method, flow of metabolizable Met was estimated using the NRC (2001) and the CPM models. Actual DMI data and assayed CP concentrations were used but library values for protein fractions were used. The estimated daily flow of metabolizable Met using the NRC and CPM models were 41 and $49 \mathrm{~g} / \mathrm{d}$ for the control cows. The Se method yielded an estimate of about $47 \mathrm{~g} / \mathrm{d}$, which is approximately $15 \%$ greater than NRC estimate and $4 \%$ lower than CPM estimate. Using net portal absorption of Met as the reference, Pacheco et al. (2006) reported that the NRC (2001) model substantially underesti- 
mated Met flow whereas the Cornell Net Carbohydrate Protein System model was reasonably accurate. Based on this evaluation, the Se method yielded reasonable estimates of Met flow for the 2 treatments. Comparing the calculated relative entry rate of Met with that obtained from nutritional models is not an unequivocal validation of the Se method. Actually measuring the true supply of Met (or any amino acid) is extremely difficult and may not even be possible (Lapierre et al., 2006), thereby making any method of estimating Met entry rate difficult to validate.

\section{Necessary Assumptions}

Our method of calculating the relative change in metabolizable Met flow requires 3 assumptions. The first necessary assumption is that the entry rate of Se-met will not influence entry rate of Met. Because the quantity of Se-met that will enter the Met pool is trivial relative to the amount of Met that enters the pool, this assumption is almost certainly valid. For example, the NRC (2001) model estimates that a dairy cow consuming $22 \mathrm{~kg}$ of DM of a diet containing common ingredients and 10\% RDP and 6\% RUP will absorb 40 to $50 \mathrm{~g}$ of Met from the intestine each day. If that diet contained $0.3 \mathrm{mg}$ of supplemental Se from Se-yeast/ $\mathrm{kg}$ of DM, all of the Se was in the form of Se-met, and $100 \%$ of that Se-met escaped rumen metabolism and was absorbed, maximum Se-met flow would equal 16.5 $\mathrm{mg} / \mathrm{d}$ (Se-met is $40 \% \mathrm{Se}$ ) or $0.04 \%$ of Met flow.

The second necessary assumption is that the entry rate of Se-met is not affected by dietary treatment. Dietary treatment could affect entry rate of Se-met if it altered the concentration of Se-met in the diet. On average, most feeds used in the US contain substantially less than $0.3 \mathrm{mg}$ of $\mathrm{Se} / \mathrm{kg}$ of DM (NRC, 2001), but concentrations can be markedly higher in feeds grown in certain regions (Hintze et al., 2001). Based on limited data, approximately $75 \%$ of the Se in common feeds is in the form of Se-met, $17 \%$ of the Se is in inorganic forms, and $8 \%$ is in selenocysteine (Stadlober et al., 2001). Therefore, if the dietary modification consisted of replacing a feed with a low Se concentration with a feed with a high Se concentration (or vice versa), then the entry rate of Se-met could change and this method could yield erroneous results. In most situations, the inclusion rate of RUP sources is low and the concentration of Se-met in the diet probably would not differ greatly between the control diet and the test diet. To determine whether this may be a concern, the concentration of Se in milk should be measured before cows are fed the test diet and when all supplemental Se is inorganic. Cows should then be changed to the test diet but it should not contain Se-yeast. If the concentration of Se in milk increases, then this method probably is not appropriate.

The third necessary assumption is that the change in concentration of Se in milk is caused by a dilution of Semet by Met and not by changes in other Se compounds. This assumption is not necessary if the concentration of Se-met is actually measured, but because of the relative ease of measuring milk Se compared with Se-met, making this assumption greatly increases the utility of the method. Available data suggest that Se in milk can be a proxy for Se-met. When Se-yeast replaced inorganic Se in a diet, 60 to $80 \%$ of the increase in milk Se was caused by an increase in Se-met (Muniz-Naveiro et al., 2007; Phipps et al., 2008). Juniper et al. (2006), however, reported that only about $30 \%$ of the increase in milk Se was caused by an increase in Se-met when Se-yeast was fed. The reason for the disparity is not clear, but analytical recovery of Se-met can be quite low depending on the method used (Polatajko et al., 2005). The analytical method used by Juniper et al. (2006) was not described. Nonetheless, the concentration of Se-met and Se in milk are highly correlated when Se-yeast is fed (Juniper et al., 2006; Phipps et al., 2008).

\section{Method Overview}

This method depends on a constant entry rate of Semet. To achieve this, the diet must contain consistent concentrations of Se-met and cows must be in steady state with respect to Se-met. Concentrations of Se-met may vary among Se-yeast sources (Larsen et al., 2004), therefore a single source of Se-yeast should be fed at a constant inclusion rate. To obtain relatively constant concentrations of Se in milk, Se-yeast should be fed for at least $7 \mathrm{~d}$ (Heard et al., 2004, 2007) before Met treatments are imposed. After at least $7 \mathrm{~d}$, milk from 4 consecutive milkings should be sampled and composited (by weight) into a single sample and analyzed for Se and N concentrations. Compositing samples from 4 consecutive milkings resulted in better precision (less cow to cow variation) than compositing samples from 2 consecutive milkings (data not shown). After those samples are collected, the Met treatment (e.g., change in protein supplement) is imposed. Diets should probably be fed for at least 1 wk before milk is sampled again. That recommended duration is based on experiments that measured portal-drained viscera metabolism of Met in dairy cows. In those experiments, treatments were fed for as little as $6 \mathrm{~d}$ before measurements started (Berthiaume et al., 2001). As with portal-drained viscera studies, our method measures change in the entry rate of Met, which in most situations occurs predominantly via intestinal absorption. After treatments are fed for at least $7 \mathrm{~d}$, samples of milk from 4 consecutive 
milkings are taken, composited, and assayed for Se and $\mathrm{N}$.

For field evaluation of diet modifications, a control diet often cannot be fed concurrently, therefore Se concentrations in milk sampled after the treatment was imposed are compared with concentrations in milk before the treatment started. If a control diet can be fed concurrently, the milk sample taken immediately before treatments started is not necessary. The number of animals required for this method is dependent on the degree of precision desired and the variation in the measurements across animals. In this experiment, Met was infused and it is doubtful that the variance between animals would be the same if Met was fed. Therefore, we cannot provide estimates of the required number of animals needed until research with oral Met supplementation is conducted.

\section{CONCLUSIONS}

Changes in the Se concentration of milk can be used to quantitatively calculate relative changes in metabolizable Met supply. The principle behind the method is that Se-met (provided by dietary Se-yeast) acts as a tracer of Met and changes in its SA (measured as $\mu \mathrm{g}$ of milk Se/g of milk N) can be used to calculate change in the daily supply of metabolizable Met. Sampling milk simplifies analytical requirements because total Se can be used as a proxy for Se-met. The Met flow calculated from the Se method compared extremely well to literature values and estimates obtained from commonly used dairy nutrition models. Because of its simplicity, this method may be useful for comparing different Met sources in both research and field situations. This method measures net changes in Met utilization at the mammary gland and includes any effects on absorption of Met from the intestines, distribution and utilization of Met to the various tissues, and mammary gland uptake of Met.

\section{ACKNOWLEDGMENTS}

Salaries and research support provided by state and federal funds appropriated to the Ohio Agricultural Research and Development Center, The Ohio State University (Paper 20/08AS). Equal additional support was provided by Adisseo Inc. (Atlanta, GA) and Evonik Degussa (Parsippany, NJ).

\section{REFERENCES}

AOAC. 2000. Official Methods of Analysis. Vol. 1 and 2, 17th ed. Association of Official Analytical Chemists, Gaithersburg, MD.

AOAC. 2006. Official Methods of Analysis. Official Method 982.30 E(a), chp. 45.3.05, acid hydrolysis. 23rd ed. Association of Official Analytical Chemists, Gaithersburg, MD.
Berthiaume, R., P. Dubreuil, M. Stevenson, B. W. McBride, and H. Lapierre. 2001. Intestinal disappearance and mesenteric and portal appearance of amino acids in dairy cows fed ruminally protected methionine. J. Dairy Sci. 84:194-203.

Casper, D. P., and D. J. Schingoethe. 1988. Protected methionine supplementation to a barley-based diet for cows during early lactation. J. Dairy Sci. 71:164-172.

Featherston, W. R., D. R. Frazeur, D. L. Hill, C. H. Noller, and C. E. Parmelee. 1964. Constancy of amino acid composition of cow's milk protein under changing ration. J. Dairy Sci. 47:1417-1418.

Gressley, T. F., S. M. Reynal, J. J. Olmos Colmenero, G. A. Broderick, and L. E. Armentano. 2006. Technical Note: Development of a tool to insert abomasal infusion lines into dairy cows. J. Dairy Sci. 89:3965-3967.

Guinard, J., and H. Rulquin. 1995. Effects of graded amounts of duodenal infusions of methionine on the mammary uptake of major milk precursors in dairy cows. J. Dairy Sci. 78:2196-2207.

Heard, J. W., A. McKenna, P. M. Shields, P. T. Doyle, G. P. Young, G. H. McIntosh, G. P. Walker, C. R. Stockdale, F. R. Dunshea, and C. M. Leddin. 2007. Increasing selenium concentration in milk: Effects of amount of selenium from yeast and cereal grain supplements. J. Dairy Sci. 90:4117-4127.

Heard, J. W., G. P. Walker, P. J. Royle, G. M. McIntosh, and P. T. Doyle. 2004. Effects of short-term supplementation with selenised yeast on milk production and composition of lactating cows. Aust. J. Dairy Technol. 59:199-203.

Hintze, K. J., G. P. Lardy, M. J. Marchello, and J. W. Finley. 2001. Areas with high concentrations of selenium in the soil and forage produce beef with enhanced concentrations of selenium. J. Agric. Food Chem. 49:1062-1067.

Juniper, D. T., G. Bertin, A. K. Jones, and R. H. Phipps. 2006. Selenium supplementation of lactating dairy cows: Effect on selenium concentration in blood, milk, urine, and feces. J. Dairy Sci. 89:3544-3551.

Koh, T. S., and T. H. Benson. 1983. Critical re-appraisal of fluormetric method for determination of selenium in biological materials. J. AOAC Int. 66:918-926.

Lapierre, H., D. Pacheco, R. Berthiaume, D. R. Ouellet, and C. G. Schwab. 2006. What is the true supply of amino acids for a dairy cow? J. Dairy Sci. 89(E Suppl.):E1-E14.

Larsen, E. H., M. Hansen, H. Paulin, S. Moesgaard, M. Reid, and M. Rayman. 2004. Speciation and bioavailability of selenium in yeastbased intervention agents used in cancer chemoprevention studies. J. AOAC Int. 87:225-232.

Lobley, G. E., X. Shen, G. Le, D. M. Bremner, E. Milne, A. G. Calder, S. E. Anderson, and N. Dennison. 2003. Oxidation of essential amino acids by the ovine gastrointestinal tract. Br. J. Nutr. 89:617-629.

Muniz-Naveiro, O., R. Dominguez-Gonzalez, A. Bermejo-Barrera, P. Bermejo-Barrera, J. A. Cocho, and J. M. Fraga. 2007. Selenium speciation in cow milk obtained after supplementation with different selenium forms to the cow feed using liquid chromatography coupled with hydride generation-atomic fluorescence spectrometry. Talanta 71:1587-1593.

National Research Council. 2001. Nutrient Requirements of Dairy Cattle. 7th rev. ed. Natl. Acad. Press, Washington, DC.

Pacheco, D., G. Raggio, H. Lapierre, C. G. Schwab, and R. Berthiaume. 2006. Comparison of net portal absorption with predicted flow of digestible amino acids: Scope for improving current models? J. Dairy Sci. 89:4747-4757.

Phipps, R. H., A. S. Grandison, A. K. Jones, D. T. Juniper, E. RamosMorales, and G. Bertin. 2008. Selenium supplementation of lactating dairy cows: Effects on milk production and total selenium content and speciation in blood, milk, and cheese. Animal 2:1610-1618.

Pisulewski, P. M., H. Rulquin, J. L. Peyraud, and R. Verite. 1996. Lactational and systemic responses of dairy cows to postruminal infusions of increasing amounts of methionine. J. Dairy Sci. 79:1781-1791.

Polatajko, A., B. Banas, J. R. Encinar, and J. Szpunar. 2005. Investigation of the recovery of selenomethionine from selenized 
yeast by two-dimensional LC-ICP-MS. Anal. Bioanal. Chem. 381:844-849.

Rulquin, H., B. Graulet, L. Delaby, and J. C. Robert. 2006. Effect of different forms of methionine on lactational performance of dairy cows. J. Dairy Sci. 89:4387-4394.

SAS Institute. 2004. SAS/STAT User's Guide, Version 9. SAS Inst. Inc., Cary, NC.

Shipley, R. A., and R. E. Clark. 1972. Tracer Methods for In Vivo Kinetics. Academic Press Inc., New York, NY.

Stadlober, M., M. Sager, and K. J. Irgolic. 2001. Effects of selenate supplemented fertilisation on the selenium level of cereals-
Identification and quantification of selenium compounds by HPLCICP-MS. Food Chem. 73:357-366.

Sudekum, K. H., S. Wolffram, P. Ader, and J. C. Robert. 2004 Bioavailability of three ruminally protected methionine sources in cattle. Anim. Feed Sci. Technol. 113:17-25.

Weiss, W. P. 2005. Selenium sources for dairy cattle. Pages $61-71$ in Proc. Tri-State Dairy Nutr. Conf, Ft. Wayne, IN.

Weiss, W. P., and J. S. Hogan. 2005. Effect of selenium source on selenium status, neutrophil function, and response to intramammary endotoxin challenge of dairy cows. J. Dairy Sci. 88:4366-4374. 